\title{
Раков В.II.
}

\section{Основные концепты поэтики неразрешимостей}

\begin{abstract}
Аннотация: Статья посвящена описанию структурных компонентов стилей Серебряного века, нашедших реализацию в произведениях А. Белого, М. Цветаевой, В. Розанова и не-которых футуристов. Их имена исследователь относит кчислу представителей, как он пишет, поэтики неразрешимостей, в которой синтезируются эпохально-характерные чер-ты не только искусства слова, но и культуры вообще. Важным фактором в миметических стратегиях творчества выступает понятие «запредельного», то есть того, что находится вне словесного контекста, будучи, тем не менее, неотрывным от него. При этом сущест-венное значение имеют такие концепты, как укон и меон, лингвистическая морфность и бесплотность в составе эстетического высказывания и стиля в целом. В статье развивают-ся идеи, изложенные в ранее опубликованных трудах автора.Ключевые слова: риторическая культура, искусствоведение, неисследимое, каллиграфия стиля, его фигурность, семантическая неопределенность и спиралевидность, открытая форма, а также хореографичность текста.
\end{abstract}

Review: The article is devoted to the description of structural components of the Silver Age styles expressed in works created by Adnrei Bely, Marina Tsvetaeva, Vasily Rozanov and some futurists. The researcher refers them to representatives of the 'poetics of insolvabilities' as he calls it. Based on the author, poetics of insolvabilities reflect the features that were typical not only for the art of writing but for the culture of that epoch in general. In mimetic creative strategies the most important role was plaid by the concept of the 'beyond the border' creativity that was beyond the verbal context and at the same time inseparable from it. The concepts of ukon, meon, linguistic morphability and insubstantiality in esthetic representations and style were significant, too. The present article summarizes and develop the ideas expressed by the author in his previous articles.

Ключевые слова: семантическая спиралевидность, семантическая неопределенность, фигурность стиля, каллиграфия стиля, неисследимое, искусствоведение, риторическая культура, хореографичность текста, открытая форма.

Keywords: semantic spirality, semantic uncertainty, figures of style, calligraphy of style, unexplorable, art history, rhetoric culture, choreography of text, open form.

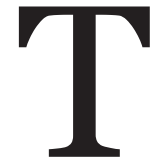

еперь, когда нам известны основные морфологические компоненты дотоле невиданной поэтики, настало время более обстоятельного их рассмотрения. Вероятно, мы будем правы, если начнём эту процедуру с обозначения того, что Платон называл высказыванием, но таким, которое свободно от оков вербальной выразительности и предстаёт во всей своей глубине, загадочности и непостижимости. Как ясно читателю, ознакомившемуся с книгой «Меон и стиль» ${ }^{1}$, нами имеется в виду область укона, обымающего текст в месте его словесного начала и в подобным же образом манифестированного завершения. При

\footnotetext{
${ }^{1}$ См.: Раков В. П. Меон и стиль Иваново-Шуя,
} 2010. $-448 \mathrm{c}$. этом выясняется, что уконические бездны располагаются не только в двух пунктах речения, но и над ними и там, внизу, куда стремится строка, заряженная жаждой своего продолжения.

«Тёмная материя» остаётся вне рационального понимания и рефлексии со стороны схемно-аналитического мышления, но как только в её мглистости обнаруживается, хотя бы слабое, присутствие признаков (вестников) Логоса, будь это точка, а тем более линия, семантически глухая морфема или же «заумь», не говоря уже о содержательно прозрачном слове, эта инфернально-бесформенная стихия трансформируется в меональную среду, сулящую и смысловую внятность, и структурно-конструктивную определённость художественной речи. 
Достигнув стадии меона, укон, однако, не исчезает, но всего лишь отдаёт себя для обработки в нечто интеллектуально вменяемое, начиная от малых и даже исходных его форм и кончая целостносмысловыми текстуальными комплексами. Так мы подошли к понятию речевого кванта, имеющего в системе новой поэтики многообразные формы и их вариации. Здесь же отметим ту функциональную его особенность, которая сопряжена с единством меональной бесплотности и некой «теловидности» (точки, линии, слова). Иначе говоря, речь идёт о понятии, сочетающем в себе логосное бытие и его отсутствие, что имеет решающее значение в деле формирования оригинальных стилевых структур. Мы уже знаем о роли квантового принципа в созидании фигурности эстетических высказываний. Но при изучении морфологии кванта необходимо сосредоточить исследовательское внимание не только на аспекте “теловидности”, но и - бесплотности, того вакуума, который актуализируется в живой ткани наррации как эмоционально-смысловая величина. Скажем и о том, что, пожалуй, основополагающей функцией квантового принципа является осуществление затактового бытия художественной речи, точнее, того её сегмента, где апофатические характеристики Логоса находят своё реальное, то есть конфигуративное воплощение. В литературоведении много пишут о контрапункте, например, стиля А. Белого, мобилизуя ресурсы риторико-классической методологии. Фиксируются случаи симбиоза прозаической и стихотворной речи в её ритмической вариативности, а вот затактовость как формообразующий фактор поэтики остаётся исследовательски не затронутым. Подобное отношение к литературным творениям Серебряного века диктуется, как мы полагаем, плохо скрываемой боязнью выйти за пределы монолитной сплошности анализируемого текста, тогда как последний настоятельно требует уяснения его дискретности, равно как без-начальности и бес-конечности. Состояние оцепенения, в которое впадает научная мысль, не даёт возможности преодолеть магический круг традиционной герменевтики, правда, не несущей ответственности за создавшееся положение дел: ведь она хорошо справлялась с во- просами, находящимися в сфере её компетенции. Специалисты в области изучаемой нами проблематики обязаны осознать то, что их привычные навыки при рассмотрении текста нуждаются в совершенствовании или вообще в кардинальных изменениях. Профессионалы-традиционалисты хорошо освоили методики работы с монолитными эстетическими высказываниями, имеющими горизонтально выпрямленный строй, лишённый непредсказуемой кривизны в расположении на странице. Такое речение начинается со слова и им же завершается. Его геометрия строга и монотонна, практически никак не сопрягаясь с тем, какое содержание выражено в тексте. Можно сказать, что знаковая реальность демонстрирует полный нейтрализм по отношению к означаемому, да к тому же выказывает своего рода герметизм, потому что высказанное всегда имеет завершение, не мирясь даже с малой дозой формальной недостроенности. Это - классика, завещанная великой риторической культурой. Однако Серебряный век - эпоха не завершённых и конечных, а - так называемых «открытых форм», по своей природе избегающих исчерпывающего совершенства художественных высказываний, преодолевающих вербальные границы и простирающихся в запредельность, туда, где располагается не словесный, а мнимый текст. Тут мы прямо сталкиваемся с выразительными системами трансфинитных структур. Эти структуры, по сути дела, из литературоведов никто специально не изучал и не описывал.

Итак, новая парадигматика творчества вырастает на смелом соединении диаметральных противоположностей в самом устроении наррации, что определяет её характерную черту как «трудной литературы», если воспользоваться выражением $\Phi$. Шлегеля. Она и в самом деле такова. Одним из её признаков выступает принцип неопределённости, фундированный в структуре текста. Так создаётся эстетическое единство вербального бытия и не-бытия, филологической реальности и её мнимости, словесной сплошности и дискретности, логосной ясности и семантической смутности или «ноологической туманности» (В. Н. Топоров), достоверности формы и её ускользания. Стили А. Бе- 
лого, некоторых футуристов, В. Розанова, М. Цветаевой - это «странный союз письма и не-письма» ${ }^{2}$, что позволяет отнести их к так называемым неразрешимым структурам, обладающим скрытыми семантическими возможностями ${ }^{3}$. Само собой разумеется, что литературные новообразования требуют дотоле не встречавшихся типов герменевтической практики, могущей справиться с задачами, стоящими перед наукой, которую отныне целесообразно именовать поэтикой неразрешимостей. Как видно, эта наука имеет дело с произведениями, включающими в себя семантическую темнотность, прерывность повествовательной ткани и актуализирующих древние формы выразительности, которые подобны шифрам, доныне остающимся неразгаданными. Порою кажется, что это какой-то эзотерический язык, не могущий не возбуждать нашего любопытства и желания приоткрыть его тайну. А она - не одна, их множество, и какую ни возьми, все связаны с вопросами редкой сложности. В самом деле, лакунарная модель текста, объятость его меональной неисследимостью - что это такое, если иметь в виду содержательную специфику новых стилей? В своё время, мы выдвинули гипотезу, в соответствии с которой тут необходимо размышлять о присутствии апофатически представленного первообраза или архитектонической формы, над чем думали А. Ф. Лосев и М. М. Бахтин. Для этой идеи описываемая поэтика даёт повод - хотя бы потому, что графически (синтаксически) означенные области меона обладают регулятивной значимостью в срезе и содержательном, и топографическом, что, собственно, определяет конфигуративный и зрелищный облик стилей новой формации.

Формулирование данной проблемы, безусловно, расширяет горизонт литературоведческого её восприятия: ведь там, где речь идёт о первообразе, неизбежно возникает вопрос об эйдосе и Логосе - в их отношениях к меонально-уконическим ресурсам развертывающихся эстетических

\footnotetext{
${ }^{2}$ Керимов Т. Х. Неразрешимости. М., 2007. С. 216. ${ }^{3}$ Там же. С. 3. Подробнее см.: Раков В. П. Поэтика неразрешимостей (подступы к теме) // Рождение культурологии в России. Сб. науч. тр. Шуя, 2011. C. $47-58$.
}

высказываний. На этом захватывающе интересном пути учёный встречается с «угрозой» не всегда верифицируемых предположений и выводов. Тут проявляет себя элемент некоторой обречённости на неудачу. Поэтолог, работающий в духе установившейся методологической традиции, испытывает чувство растерянности при встрече с материалом, не поддающимся привычному истолкованию. Он имеет дело с текстами усложнившейся структуры, основанной на высокой дозе семантической неопределённости и топографической безмерности. Ему необходимо такое восприятие написанного и, добавим, буквально начертанного художником, которое позволило бы восчувствовать и осмыслить текст в вероятностносимволическом ключе и никогда не замирающей процессуально-филологической неугомонности. И если мы можем с вполне достоверной явственностью понимать и комментировать вербализованные сегменты стиля, то там, где располагается, растекаясь, тьма запредельного, нам приходится напрягать эстетическую интуицию, чтобы извлечь из неисследимого марева какие-то смысловые токи, которые, как ни горько признать это, далеко не всегда могут помочь реконструировать хотя бы интенциональный пафос замысла писателя. В наших силах - указать на тайну, но полностью расшифровать или, тем более, исчерпать её было бы самонадеянным намерением. Однако хорошо уже то, что мы уразумели важность совета о. П. Флоренского: при познании мира следует не аннигилировать его тайну, а понимать её включённость в онтологию явлений. Всё вышесказанное побуждает к размышлениям о строительно-творческом алгоритме новых стилей.

Как известно, в классике стильность предуказывается тенденцией к семантической ясности и чёткой структурированности исходных и развёртывающихся речений, тогда как в некоторых стилях модернизма художник находится в «обстоянии» таких стихий, которые диктуют ему своеобразное послушание и, вместе с тем, требуют властного их обуздания. Что это за стихии, мы уже знаем: ранее нами исследовались не только энергийные возможности Логоса, но и бушевание меона, часто уходящего в уконическую глубину и 
глушь. Можно сказать так: установив среду обитания творческого духа Поэта, нам необходимо понять тот принцип, с помощью которого литературный дар писателя стремится к осуществлению волнующего его замысла. Отныне творец обращается к созидательному потенциалу того «безумия», которое возжено в нём богами Греции и Рима, Сивиллой, пророками, праведниками и шаманами. Прозорливость умного ви́дения и проникновенная эмпатия интуиции снимают с него тяготы риторических правил и ограничений, взамен чего даётся безграничная свобода делания. Но нам менее интересны общие рассуждения о процессе творчества, нежели конкретные представления о нём. Поэтому напомним, что сочиняемый текст находит свою подлинно эстетическую реализацию - в стиле, в его основных матрицах, в воспроизведении чувственного трепета мировой целостности и её внутренних взаимосвязей. Однако для понимания стиля этого мало. Свежесть, необычность, то есть оригинальность творчества знаменуют собою то, что у Б. Пастернака обозначено словом «впервые». Речь идёт о художественном прецеденте, о чём-то невиданном и небывалом. Иначе говоря, - о чуде. Оно начинается с минимальной языковой величины, разрастающейся на странице до неохватных масштабов космической проекции, представленной в поэтологической выстроенности и поданной как артистически обработанный стиль. Несмотря на формульно выраженную здесь мысль, всё же, надеемся, не будет навязчивым вопрос: какой элемент текстовой структуры можно полагать в качестве исходного события стиля? Мы ответим на это так: квант - (из)начальная единица эстетического речения. Его поведение в стилевой среде непредсказуемо, если не сказать - иррационально. Размер такого речения всякий раз неодинаков, что определяется многими факторами, включая сюда как психологические, так и собственно текстуальные. Эта модель письма обладает высокой степенью окказиональности; тут правомерно говорить о свободе образования эстетических высказываний, напоминающих примеры стилистических вольностей эпохи романтизма, хотя и не играющего роли основного и единственного источника новой поэти- ки. Однако скажем о существе дела, о том методологическом алгоритме творчества, о котором шла речь выше. Для этой цели будет полезным обратиться к работе О. Мандельштама «Разговор о Данте». Мы прибегнем к извлечению из текста лишь некоторых суждений поэта - и не столько потому, что какие-то из них, по признанию современного исследователя, «не без тёмных мест, недоступных пониманию комментаторов», иные же, «сами по себе интересные и глубокие, не имеют прямого отношения к интерпретации творчества Данта» ${ }^{4}$ Вероятно, здесь не помешает оговорка. Во-первых, по поводу «тёмных мест». Насколько это определение адекватно качеству текста Мандельштама, видимо, можно спорить. Во-вторых, «об интересных и глубоких» высказываниях поэта, охарактеризованных как некое излишество в системе дантологии, также допустима дискуссия с привлечением историков зарубежной литературы и её теоретиков. Так, например, Л. Е. Пинский, в своё время, писал, что «от этюда Мандельштама исходит сильный и резкий свет на многие важные образы и грани «Комедии», оставшиеся тёмными при традиционном аллегорико-пластическом освещении» 5 . Нам представляется, что возможно усиление этой позиции за счёт указания на то, что идеи Мандельштама были сформулированы в атмосфере, впитавшей в себя идеологию различных поэтик с их методолого-философской и филологической свободой, дотоле небывалым отношением к синтаксису, новаторским истолкованием проблемы формы и содержания и т. п. Данная тематика рассмотрена в статье Л. Е. Пинского, мы же, следуя за ходом мысли Мандельштама, введём его соображения в контекст нашего исследования. Начнём с напоминания о том, что изучаемым нами стилям присущи и бесформенность (в них, как отмечалось, нет ни начала, ни конца), и «бессодержательность» - в том смысле, что «идейность» дана здесь не только в

\footnotetext{
${ }^{4}$ Илюшин A. А. Данте и Петрарка в интерпретациях Мандельштама // Жизнь и творчество О. Э. Мандельштама: Воспоминания. Материалы к биографии. «Новые стихи». Комментарии. Исследования. Воронеж, 1990. С. 374.

${ }^{5}$ Пинский Л. Поэтика Данте в освещении поэта // Пинский Л. Магистральный сюжет. М.,1989. С.374.
} 
образе абсолютизированной вещи, тела, человеческого лика, но и в виде некоего необъятно-безграничного пространства, обымающего эти зрительно воспринимаемые изображения. То, о чём пишет Мандельштам, мог бы поддержать любой из приверженцев новой поэтики. В «Разговоре о Данте» читаем: «Поэтическая материя не имеет голоса. Она не пишет красками и не изъясняется словами. Она не имеет формы точно так же, как лишена содержания, по той простой причине, что она существует лишь в исполнении. Готовая вещь есть не что иное, как каллиграфический продукт, неизбежно остающийся в результате исполнительского порыва. Если перо обмакивается в чернильницу, то ставшая, остановленная вещь есть не что иное, как буквенница, вполне соизмеримая с чернильницей ${ }^{6}$.

Приведённый фрагмент весьма показателен, хотя и, в какой-то степени, относится, если согласиться с вышеупомянутым исследователем, к числу не совсем понятных. Но посмотрим на этот текст с точки зрения новой поэтики. Его содержание, и это - правда, «странно»: определяемая здесь «поэтическая материя» мыслится апофатически, ведь она «не имеет голоса», «не пишет словами», она, наконец, бесформенна. Но её природа онтологична и находит своё осуществление в исполнении, результатом чего является «каллиграфический продукт» или «буквенница», сопоставимая с «чернильницей». Тут что не слово, то загадка. К которой, всё же, имеется ключ. Тезис поэта начинается с фиксации обсуждаемой «материи» и с отрицания у неё каких-либо необходимых для творчества качеств. Она - допредикативна, то есть находится во тьме и гуще меона как стихии небытия. Однако в ней вспыхивает созидательный импульс - именно тогда, когда возникает возбуждающая энергия исполнительства, иначе - тогда, когда пробуждается активность Логоса, где буква - его вестник и начальный элемент письма («каллиграфии»). В метафорически насыщенном дискурсе Мандельштама набросана картина возникновения речения-письма-

\footnotetext{
${ }^{6}$ Мандельштам О. Соч.: В 2 т. М., 1990. Т. 2. С. 253. Далее ссылки на это издание приводятся в тексте с указанием страниц в скобках.
}

стиля- и, в целом, словесного творчества. От меона - к Логосу: такова траектория этого процесса. Данная мысль укрепляется заключительным предложением фрагмента, где говорится об акте творения, но уже в лапидарном виде с эксплуатацией мотива «чернотности», с которой соизмерим появившийся из её глубин текст, несущий на себе признаки семантической смутности, конечной непрояснённости, равно как и её живой трепет, но мы, сожалеет Мандельштам, «разучились описывать то единственное, что по структуре своей поддаётся поэтическому изображению, то есть порывы, намерения и амплитудные колебания» (с. 247). Художник использует спонтанное психофизиологическое воздействие слова на собеседников (читателей), а также средства, «которыми он передаёт порыв к говоренью, то есть сигнализирует светом внезапное желание высказаться».

«Здесь, - [для нас этот пункт «Разговора...» очень важен], - он ближе всего подходит к волновой теории звука и света, детерминирует их родство» (там же).

Мандельштам часто удивляет. Так и в нашем случае. Не являясь исследователем новаторской формы художественного творчества, он, воспринявший её с высот классической культуры, сформулировал такие особенности предмета, какие были неведомы литературоведам - его современникам. Да, судя по всему, и ныне теоретические высказывания поэта некоторым филологам ещё предстоит освоить должным образом. Но - пойдём дальше и обратим внимание на не менее существенные наблюдения, изложенные в эссе.

Художественная речь новой конфигурации, как было отмечено, основана на принципе прерывности и волновости, что, естественно, вступало в противоречие с синтаксисом традиционного типа. Об этой новизне написано так: «Нет синтаксиса - есть намагниченный порыв» (с. 250), в результате чего словесные массы слагаются не в сплошную горизонтальную структуру, а в криволинейно организованный, зрелищно выразительный стиль, чья фигурная специфика далека от издавна утвердившихся словесно-комбинаторных форм. Её логика таинственна в своей освобождённости от каких-либо правил лингво-стилистического развёртывания. 
Она - импровизационна. Как мы знаем, в процессуальности текстового возрастания принимают участие не только слова и «буквы», о чём пишет Мандельштам, но и графика, а-грамматически (окказионально) трансформируемая нуждами поэтологических заданий. Общее представление о том, что́ есть текст - в нашем понимании, не расходится с соответствующими суждениями, изложенными в «Разговоре о Данте». Там написано: «Каллиграфическая композиция, осуществляемая средствами импровизации, - такова приблизительно формула <..> порыва, взятого одновременно и как полёт и как нечто готовое. Сравнения суть членораздельные порывы» (с. 253). Мы полагаем, что эта теоретическая максима может быть соотнесена с конкретной морфологией новых стилей - с целью её содержательного декодирования. Так, например, слово «полёт» здесь означает многое: и просторность, в которой находятся лексические составляющие стиля, и космическую необозримость, предшествующую тексту и растекающуюся за его вербально очерченные границы. Иначе говоря, это слово связывает наше воображение с запредельным и его неисследимостью. Точно так же и слово «порыв» включает в себя самые разные значения: «текстильные, парусные, школярские, метеологические, инженерийные, муниципальные, кустарно-ремесленные и прочие порывы, список которых можно продолжать до бесконечности» (с. 254). И всё это претворяется в лингвопоэтологическую среду текста, данного в модусе свободной, как бы непрограммируемой («несемиотичной») импровизации. Так что главенствующим моментом творчества, по Мандельштаму, правильнее было бы считать «порывообразование, а не формообразование» (там же). Применительно к нашей теме этот вывод как нельзя более реалистичен. В самом деле, ведь мы имеем дело с феноменом «открытой формы», отличающейся от её варианта в системе классического искусства. Если так можно выразиться, режим творческого процесса, основанный на аритмологии «порыва» и «импровизации», противоречит мерности традиционного текста, где слово - всегда «на виду» и в колее заданного ритма. Литературная практика А. Белого, В. Розанова, М. Цветаевой и дру- гих художников показывает, что слово, наряду с различными формами своей манифестации, обладает ещё и даром исчезновения, что и создаёт эффект открытости отдельных речений и стилевых структур. Повторим нашу мысль о том, что такое поведение слова - иррационально. Другим оно и не может быть, потому что его истоки находятся в непостижимых меонально-уконических безднах космичности или того иного, где рождается мир в его комбинаторных (синтаксических) связях и смыслах.

Заключая очерк, Мандельштам пишет, что в будущем «предметом науки станет, как я надеюсь, изучение соподчинённости порыва и текста» (там же). Задача не из лёгких. Но уже сейчас имеются, хотя и немногочисленные, примеры удачного использования семантических, шире - когнитивных и эстетических возможностей становящегося исследовательского метода7 ${ }^{7}$ Напряжённые размышления поэта, помимо и спорных, и истинных, равно как и проникновенных мыслей, демонстрируют понимание автором холотропности искусства, каким бы разнообразным и «непохожим» оно ни было в своём историческом бытии. Имея дело с классикой, усматриваешь её «гены» в творчестве более позднего времени,

7 Степанов Ю. Мыслящий тростник. Книга о «Воображаемой словесности». Калуга, 2010. Здесь, в частности, излагается программа авторского исследования с выделением в ней трёх «Суперкатегорий»: Экзистенции (Экзистенциала), Логоса и Изоса (изо - темы, изо - тематизма). В книге подчёркивается, что в содержание названных понятий входит и «что-то «затекстовое». Причём даже не только то, что уже зафиксировано в виде печатных публикаций, текстов и т. д., а и то, что ощущается в этой области, даже и не будучи ещё выраженным, можно сказать, «затактовые звуки», предшествующие мелодии, - «гул» Маяковского и т. п. Мандельштам говорил, что у него стихи существуют до того, как они записаны» (c. 10). Эти примеры можно умножить и рядом иных, заимствованных не только из литературного, но и музыкального, скульптурного и архитектурного творчества. То же следует сказать и о произведениях дискурсивного характера - физики, математики и т. п. Если Ю. С. Степанов относит подобные примеры к плану затекстового, то в системе терминологического языка, принятого в нашем исследовании, они находятся «под сенью» меона и уконических бездн. 
отчего предшествующие стили и их методологические техники становятся яснее и глубже, чем мы думали ранее. Вероятно, здесь наблюдается эффект «единства противоположностей, дополняющих друг друга <...> и гарантирующих равновесие своим взаимоупором» ${ }^{8}$. Мы полагаем, что при изучении эволюции литературного творчества, да и, пожалуй, культуры вообще, рассмотрение прерывности этого процесса требует большей осмотрительности, нежели это принято ныне под воздействием «летучих» идей и веяний.

Воспринимая описанную ситуацию и её теоретическую актуальность, мы всё же ограничимся рассмотрением лишь узкого круга тематизируемых проблем. Наша задача заключается в том, чтобы указать на факт обретения искусством таких ресурсов, с помощью которых художник расширяет возможности творческих стратегий в области структурно-конфигуративного устроения стилей. Изучая новую поэтику, мы как раз и видим это. Ясно, что данный процесс протекает в контексте свершившегося переворота, связанного с отказом от некоторых заветов классики, в частности, от языковой монолитности текста как основе традиционной риторичности высказывания. В наше время о таких явлениях пишется много, причём нередко - c подчёркиванием обертонов тоталитарности и репрессивности классических моделей речи 9 . В подобных трудах много интересного и правдивого, но нам, признаемся, жаль, что бросается камень в риторику, она, как известно, бессмертна: ведь «пост-язык» с его лексическим плюрализмом и синтаксической свободой не в силах пренебречь правилами говорения и письма, завещанными классической культурой. Не будем тревожить тень пресловутого Журдена. Полезнее сказать о том, что риторичность наших речений часто существует в потаённости, и если «новояз» отрицает общепринятые каноны коммуникации, то в любом случае он позиционирует себя по отношению к неубиенной языковой и стилистической норме. Но оставим эту тему и перейдём к непо-

\footnotetext{
${ }^{8}$ Аверинцев С. С. Поэтика ранневизантийской литературы. М., 1997. С. 252.

${ }_{9}$ См., напр.: Кристева Ю. Избранные труды: Разрушение поэтики. М., 2004.
}

средственно важным для нас вопросам, первым из которых следует признать тот, что прикосновенен к телеологии художественных стилей. По необходимости будем кратки и начнём с того, что в классике идея целостности находит реализацию в таких эстетических формах, принцип организации и внутритекстовых сцеплений которых ориентирован на модель «Мирового древа» (Arbor mundi). Каждый элемент здесь пронизан токами архетипного образа, символизирующего жизнь космоса в его вселенскости и человековедческой значимости. Произведение искусства соотносимо и соизмеримо с ним, с этим образом. Несмотря на универсализм семантики последнего, он всё-таки мыслится в своей граничности, имея начало, середину (ствол) и завершение. Исследователь новых стилей понимает, что их устроение опирается не только на этот традиционный принцип. Их морфология включает в себя и многое из того, что не наблюдалось в предшествующем искусстве. Это небывалое допустимо рассматривать с различных позиций. В должном месте нашей монографии «Меон и стиль» мы писали об эффективности сопоставлений текстовой структуры в произведениях А. Белого и других художников с картиной небосвода, как она запечатлена в сочинениях Демокрита, считавшего, что трагедия и комедия, эти символы литературного чуда в античной Греции, есть не что иное, как некие множества, состоящие из слов-атомов, выстроенных в определённом порядке. У нас нет необходимости следовать этой наивной концепции, но было бы в духе данной традиции, если бы мы сочли стиль за словесно выраженную проекцию космоса, тем более, что нашлись бы и основания для подобного образа мысли. Современная космология оперирует такими терминами, как меон и укон. В наших представлениях о творчестве они играют значительную роль в функционально-динамической системе стилей. Однако сейчас, по прошествии целого века с тех пор, как эти категории были привнесены в филологические исследования, есть смысл в попытке рассмотрения их действенности - в свете ныне популярных теоретико-методологических конструкций. Одна из них - ризома, без анализа которой редко обходится какое- 
либо гуманитарное исследование ${ }^{10}$. Эту конструкцию предложили Ж. Делёз (основной коэффициент участия - за ним) и его соавтор $\Phi$. Гваттари ${ }^{11}$. В последнее время среди филологов возрастает интерес к упомянутой дефиниции и стремление использовать её при осмыслении некоторых специальных вопросов в области теории речевых актов. Как понятие ризома, на наш взгляд, может быть включена в инструментальный аппарат исследователей структурных особенностей неклассических стилей. Правда, сказанное нельзя абсолютизировать. Мы настаиваем на том, что изучаемая нами поэтика нуждается в таких критериях, которые оберегали бы её от унифицирующего терминологического языка. «Ризома» - не средство тотального измерения нарративных практик Серебряного века, а всего лишь ключ к пониманию каких-то их признаков. Так, например, ризомная схема предусматривает момент дискретности тех или иных явлений и реального мира в целом. Тут она совпадает с принципом прерывности и лакунарности телеологически организованных эстетических высказываний. Надо видеть и то, что ризома предполагает феномен срединности, в которой концентрируется энергия и сущность происходящего процесса развития. Это положение достойно того, чтобы быть осмысленным, но уже в нашем материале, именно, в лингво-поэтологической среде. То же самое относится и к некоторым постулируемым признакам ризомы, обладающим способностью внезапного исчезновения в параллель тому, как это происходит в «лоскутной» ткани повествования А. Белого или В. В. Розанова. Обратим внимание и на тот из аспектов учения о ризоме, который до сих пор не нашёл творческого отклика со стороны специалистов по русской литературе рубежа XIX-XX веков. Мы имеем в виду тезис Ж. Делёза и Ф. Гваттари об «органицизме» их мировоззрения. Для мыслителей проблематика, какой бы она ни была по своим масштабам, залегает в космо-онтологическом контексте, точнее, в его пространствен-

\footnotetext{
${ }^{10}$ См., напр.: Дугин А. Г. Логос и мифос. Социология глубин. М., 2010. С. 215 и след.

${ }^{11}$ См.: Делёз Ж., Гваттари Ф. Ризома // Философия эпохи постмодерна: Сб. переводов и рефератов. Минск, 1996.
}

ных координатах, тесня при этом значимость категории времени ${ }^{12}$. В пункте «органицизма» как раз и пересекаются научно-философские дискурсы, словесноэстетическое творчество новой парадигмы и художественная классика. Во всех этих случаях требуется анализ воспроизводимой картины мира и человека, где Логос не только властвует, но и нередко уступает место активности меональных сил, ни при каких условиях не поддающихся окончательной аннигиляции, даже если мастерам пера и кисти удаётся укротить эту стихию посредством символических смыслов. Кроме них, указывает современный исследователь, «иконология ещё и говорит о том, как в этом упорядоченном здании звучат голоса дочеловечности и докультурности, отголоски биокосмических энергий первобытного существования» ${ }^{13}$. Да, меон не устраним как из истории, так и из жизни личности, при этом заметим, что космическое начало амбивалентно: с одной стороны, оно обладает импульсами порождений - не только природно-физических объектов, но и высших идеальных структур, как-то: наука, искусство и культура в её многообразном целом. С другой стороны, не забудем, что открывающаяся перед нашим взором панорама плодящегося и умножающегося вещества, будь это грубый камень, животное или утончённая мысль, несёт в себе, как Земля - магму, мощь устрашающих стихий, тёмной людской психологии и инфернальных образов. Эпоха «осевого времени» средиземноморской культуры справилась с жизненно неотложной задачей: она подавила угрозу со стороны меональных сил, сметающих на своём пути всякий лад, гармонию и красоту. Теперь слепая энергия стала служить культурно-созидательным целям, при этом не истощаясь и не исчезая, на-

\footnotetext{
${ }^{12} \mathrm{O}$ проблеме времени, её сложности и о том, что «время Делёза (поствремя) постепенно (пока через научную и культурную элиту) вступает в свои права», см.: Дугин А. Г. Социология воображения. Введение в структурную социологию. М., 2010. С. 137 - 138. Подробнее о концепции времени Ж. Делёза см.: Дугин А. Постфилософия. М., 2009.

${ }^{13}$ Якимович А. Генрих Вёльфлин и другие: О классическом искусствознании неклассического века // Вёльфлин Г. Ренессанс и барокко. Исследование сущности и становления стиля барокко в Италии. СПб., 2004. С. 39.
} 
поминая могущественное «са́мое самó» (термин А. Ф. Лосева). Она остаётся тем, что́ есть, будучи превыше всякого бытия и всякого мышления (Платон). Мы должны считаться с её спонтанностью, алогичностью и, как следствие, непредсказуемостью появления там, где она «хочет». Теория ризомы, изложенная в форме не столько строгого дискурса, сколько в духе поэтического прозрения, не озабочена каузальным обоснованием «плато», как это названо Ж. Делёзом. Тем не менее, перечисленные характеристики необходимо держать в горизонте нашего вúдения, чтобы ярче прояснить принципы структурации стилей определённого типа. Но тут мы оказываемся в ситуации возможного недоумения. В самом деле, располагает ли исследователь надёжными средствами и способами, например, синтаксического анализа эстетических высказываний, если само их возникновение и место бытования в тексте, а также их фигурный облик находятся вне какойлибо рациональной мотивации? Это требует от филолога внятных логических аргументов. Увы, таких аргументов мы не найдём, да и надо ли утруждать себя подобными поисками? Для специалиста, живущего в атмосфере сциентизма, эта оговорка означает открытую симпатию к агностике, хотя существо дела говорит об обратном. Поясним сказанное.

Серебряный век открыл такое множество проблем и методов их изучения, что до сих пор не составлен сколько-нибудь полный их перечень. В этом ряду мы хотели бы выделить принцип неопределённости, которым оперировали не только математики, физики и философы, но и люди, писавшие о литературно-художественном творчестве, - такие, как, например, энциклопедист о. П. Флоренский. Мыслитель мобилизовал этот принцип при формулировании идеи тайны как онтологического свойства мира, в чём, собственно, и заключается его чудо. Мы писали о его суждениях, касающихся методологии науки, удаляющейся от устаревающих представлений, в соответствии с которыми необходимо, говоря современным языком, всё деконструировать, то есть уложить в рамки вполне доступных рационализированных схем, тогда как, напротив: явление, сколь бы глубо- ко оно ни было изучено, не должно подвергаться редукционистским упрощениям. Долг учёного - сохранить целостный образ предмета, включая и момент его тайны. Мы можем выстроить картину мира, интерпретировать её и дать описание уровней и отношений между ними. И не исчерпать смысл узнанного, потому что оно простирается в прошлое и будущее незнаемого. Кажется, мы говорим общеизвестное, но в таком случае романтизм, внёсший огромный вклад в познание таинственного, окажется собранием прописных истин, не так ли? В конце концов, можно сказать иначе: структура ризомы и новых стилей имеет такие сегменты, которые поддаются описанию и уяснению их значимости. Однако рядом располагается и то, на что мы способны лишь указать, но не ответить на вопрос: почему это сделано так и что́ конкретно оно означает? На первую часть вопрошания не смог бы ответить и сам творец стиля, захваченный загадочной процессностью порыва и импровизации. Что же касается содержания лакун и разрывов в лексической массе, а также её меональной объятости, то тут без обращения к интуиции воспринимающего не обойтись. Надо быть готовым к вышеназванному принципу неопределённости. Он-то и уводит герменевтическую стратегию от неуклюжести излишне прагматических толкований текста. Однако он же и не даёт успокоения, заставляя наш ум бодрствовать, к сожалению, нередко - бесплодно. Что делать! Мыслительная работа доставляет человеку не только радость. Очевидно, что, кроме удовольствия, о котором так много говорят, она привносит в наше самочувствие элемент огорчения, а то и страдания. Но, к счастью, мы находимся не в безнадёжном положении. Попытаемся продвинуться в понимании неопределённости в системе стилей.

Начнём с того, что их структура организована таким образом, что каждое из включённых в её состав речений в той или иной мере обладает размытостью семантики. Тут что-то не договаривается, словесно не выражается, находя своё место в лакунарной пустоте, в обрыве нарративной сплошности, а также в наэлектризованной токами неясного, но угадываемого содержания той стихии, в окружении которой живёт - так мы име- 
новали его ранее - само себя, человека и мир мыслящее слово. Представьте это слово вне указанной среды, и вы получите обескровленную схему текста. То, что делает стиль живым, трепещущим (повторим это определение!), достигается за счёт «сквожения» (М. Цветаева) в нём и вокруг него вот этого аморфно данного эмоционально-смыслового паттерна, как основы невыразимого. То, что находится в запредельности слова, создаёт его полноту и эффект несказа́нности ${ }^{14}$.

Такое устройство системы художественной коммуникации имеет свои следствия, о главном из которых мы уже успели сказать выше. Здесь имеется в виду легитимизация вероятия как принципа суждения о тексте. Читатель теперь имеет возможность узревать в лежащем перед ним фрагменте или произведении большее число смыслов, чем в повествовании, созданном по классическим образцам. Предложенная ему каллиграфия - провокативна и действенна; её суггестия - многоканальна, ибо побуждает воспринимать написанное в модусе его объёмности, то есть не только как смыслообраз, но и в качестве реально созерцаемого объекта-артефакта. Это и понятно: ведь новые стили не только содержательны, но и активно зрелищны, конфигуративны, а это значит, что они имеют не один и не два, а бесчисленное множество пунктов источающейся из них эстетической информации, которая обрушивается на читателя-зрителя. Мы должны учитывать сложность самой проблемы. Искусство письма вступило в такую стадию развития, когда каждый элемент начертания взывает к его, в том числе и докультурному, восприятию, воскрешая память о доисторической тьме существования рода человеческого.

Сложность «запредельного» состоит в его энергии, создающей возможность усматривать в речевых разрывах, в до- и посттекстовых безднах самое разнообразное содержание, не имеющее семантической определённости и потому интригующее читателя, подвигая его к догадкам, а

\footnotetext{
${ }_{14}$ Подробнее см.: Раков В. П. Стратегия языкового расширения научного дискурса как реализация антикризисного потенциала культуры // Бесконечная равнина: Антикризисный потенциал русской интеллектуальной культуры конца Нового времени. Иваново-Шуя, 2010. С. 29-33.
}

также к свободным и даже произвольным ассоциациям. Однако, поскольку не существует какого-то одного типа читателя и в освоении произведения принимают участие люди с самыми разными познавательными и эстетическими установками, подвергающимися воздействию на них индивидуализированных, часто генетически предопределённых качеств, то стили как зрелищные конструкции снимают многие преграды на пути их вольного, чтобы не сказать - волюнтаристского, восприятия и интерпретаций. Во всяком случае, в сравнении с дискурсивно-поэтологической дисциплиной классики, здесь больше возможностей и соблазнов, дабы утвердиться в мысли об относительности всякого рецептивного акта. Суждения литературоведов по поводу того, что они именуют сотворчеством писателя и читателя, применительно к новой поэтике звучат более убедительно, нежели в связи с художественными творениями классического образца. Однако это не даёт никаких оснований подвергать сомнению избранную нами стратегию с целью установления объективно-структурной типологии стилей, имеющих, как мы видим, вполне оригинальное устройство. Здесь уместно напомнить, что телеологически выстроенные конструкции состоят из сегментов вербального характера и того, что нами означено как мнимый текст, представленный синтаксическими маркёрами - точками и линиями, а также их отсутствием на других меонально-выразительных участках, которые, тем не менее, вовлечены в общий план эстетических высказываний. Новая поэтика по своей морфологической составности и координированной связности частей исходит не из правил грамматического контроля над подобными речениями. Иначе говоря, она организует стиль не в модусе его гомогенности, отступая от этого принципа и стремясь к такой компоновке словесных и внелингвистических материалов, которые прямо указывают на гетерогенность художественной речи. Тут намеренно ставятся в один ряд языковое бытие и небытие, Логос и меон, внезапное исчезновение слова и столь же неожиданное его возвращение в систему функционально нагруженных динамических кривизн стиля (М. Цветаева). То же самое относится и к 
сверхвербальной, то есть «графической риторике» (Ж. Деррида). Но что же следует из этого? Результатом указанного процесса является качественное изменение поэтологической типологии художественно-речевого построения. Если в классике содержательное ядро произведения и его образной системы обогащается за счёт возрастания семантических и сенсорных ресурсов внутренней формы, не выходящей за пределы словесно-синтаксической монолитности, то новая поэтика увеличивает свою когнитивную и эмоциональную энергию путём разрушения сращённости, внешней герметичности речевого потока, тем самым обеспечивая себя дотоле небывалыми источниками эстетизированного содержания. Такая речевая структура эволюционирует в сторону ярко манифестирующего себя метатекста. Кажется, мы не сказали того, что можно было бы счесть за новость: ведь классические стили имеют все признаки метатекстовых образований. Однако, чтобы обнаружить это их свойство, надо приложить немалые аналитические усилия с проникновением в мифологическую и символическую подоснову эйдологии творчества художников. Новая поэтика как бы пренебрегает «стыдливостью формы», предлагая взамен тотальную её открытость. Даже маломальски образованный филолог увидит здесь то, что русские «формалисты» разумели под «обнажением приёма». Правда, сегодня преждевременно думать об исчерпанности тайны нетрадиционной поэтики, ибо в ней ничуть не меньше и мифологии, и, конечно же, нерасшифрованных смыслов, которые, видимо, по своей загадочности и глубине уж никак не уступают предшествующему литературному наследию...

Как мы неоднократно указывали, фигурность стилей, их лакунарные «провалы» в бездну, удивительно разнообразная и виртуозно используемая «графическая риторика» создают «вогнутость» и «выгнутость» текста, в котором его дискретность практически никогда не утрачивает своей значимости. Перед нами тот случай, когда геометрия стилей напоминает живописные композиции, где намеренно оставлены некие матрицы (теперь можно сказать так:) как приют молчания. Ведь при чтении написанного интенсивная интервальность речи как раз и требует в нужных пунктах безмолвия, что в классике, в силу лексической уплотнённости эстетических высказываний, допускалось едва ли не в исключительных случаях. Так мы подошли к одному из всемирно-исторических символов (С. С. Аверинцев), без которого ни один стиль неклассической формации непредставим. Ну, а если мы имеем дело с символом, то надо быть готовым к его сложной структуре и многофункциональному спектру его свойств в системе текста. Здесь же приведём одно из наблюдений современного исследователя, касающееся, в частности, творчества В. Розанова, который, тяготея «к «священному безмолвию», почувствовал неожиданные неисчерпаемые возможности феномена молчания, когда отсутствие Слова как такового является в стилистическом и семантическом плане более значимым, чем его наличие» ${ }^{15}$.

Необходимо помнить, что структура нового литературного письма укоренена в до- и исторических далях культуры, прежде всего, в тех её формах, которым близки начертательные технологии, объединявшие начала не только письма, но и геометрии, строительного искусства и архитектуры, не говоря уже о всякого рода схематике, контурном рисунке, а также - живописи, обучение которой, как известно, и в наше время начинается с овладения линией и её различными видами. Вот почему новые стили (напомним в который раз!) зрелищны. В наших исследованиях была зафиксирована и такая их особенность, как хореографичность, танцевальность, причём, высочайшего уровня. Фигурность их развёртывания зависит от импровизационных ритмов, часто весьма далёких от их классических вариантов.

Наряду со спецификой зрительного плана, изучаемая поэтика несёт в себе и то, что гнездится в вышеупомянутых матрицах бесформенности, чем, заметим, и является молчание. Что же касается В. Розанова, то безмолвие в его творениях, как, впрочем, у М. Цветаевой и других художников, имеет подтекст или ауру сакральности. Так что модернизм,

${ }_{15}^{15}$ Налепин А. Л. Феофан // Розановская энциклопедия / Сост. и гл. ред. А. Н. Николюкин. М., 2008. С. 1048 . 
как отмечалось, не только эзотеричен, но и, пожалуй, мистичен в своей структурнохудожественной выразительности. Ещё раз акцентируем мысль о том, что вся эта специфика базирована на основе принципа визуальности, ибо стили, о которых идёт речь, конфигуративны; столь же актуален здесь и принцип аудиальной (слуховой) культуры, ибо если писатель активно использует функциональность молчания, то, следовательно, он не может пренебречь и фоноцентричностью высказывания.

Итак, новые стили как неведомые дотоле конструкции выстроены в модусе noказа самих себя, причём не только в срезе неожиданной, загадочной, своевольной и даже капризной геометрии, демонстрирующей тяготение к живописному порядку/ беспорядку, но и в аспекте разрушения и исчезновения того, что на наших глазах развивалось и восхищало своими извивами. Для обозначения этого динамического процесса в литературоведении имеется термин - «орнаментальность», но его семантика не в полной мере учитывает то обстоятельство, что в самом-то орнаменте «пустотные» его зоны столь же, если не более, важны, как и их точечно-линеарные основы. Так что редукция сегментов безмолвия здесь недопустима. В целом же, новая модель телеологической структуры дана в виде словесно-графической композиции с утверждёнными в ней принципами фигурной наглядности, звукового резонирования и тишизн (М. Цветаева), в интимной глубине которых существует само себя мыслящее слово. Оно же и режиссирует онтологию всего метатекста - с позиций его внутренней функциональноосознающей себя Психеи и с точки зрения внешней его наблюдаемости, регулируя, таким образом, читательскую реакцию на созерцаемое, слышимое и безмолвствующее содержание импровизационного построения.

Поэтика неразрешимостей даёт повод для различных ассоциаций, в том числе и историко-культурного характера. Так, например, вряд ли кто будет возражать, если мы укажем на то, что восприятие структурных особенностей стилей, говоря по-старинному, с высоты птичьего полёта, воссоздаёт образ своеобразного лабиринта. Как известно, в мифологии древних греков лабиринт - это дворец, из которого невозможно найти выход. Но ариаднина нить спасла Тесея. Этот памятник архитектурного гения Дедала имеет праобраз - египетский лабиринт, насчитывающий 3000 комнат под землёй и над землёй ${ }^{16}$. Сравнение новых стилей или, как выражался В. В. Виноградов, их «лика» с лабиринтом, можно признать удачным. Но тут есть над чем подумать. Прежде всего бросается в глаза хорошо обнаруживаемая идея запутанности - в одном случае в проекте здания, в другом - текста, что не может не пересекаться с энигматичностью поэтики, о которой мы пишем. Существенна и такая деталь, как указание на «верх»и «низ» лабиринта. В противоположность классическому дискурсу с его горизонтально-последовательной выпрямленностью, в системе творчества вышеупоминавшихся художников заострённо актуализируются собственно топографические координаты эстетических высказываний; их расположение на странице - не стандартно и «не канонично», а дано в космической разбросанности - в формах вербально-графической выраженности верха и низа [их местоположения]. Соотношение того и другого - своего рода тайный знак гомогенности речений, составляющих стиль. Но как возможно такое? Ведь мы имеем дело с лингво-эстетическим материалом, который обладает высокой свободой в деле собственных формообразований, не поддающихся воздействию на них унифицирующих принципов. Хореографичность стилей уводит их от поэтологических норм в пространство безмерностей, преследуя «показательные цели символической космологии и, одновременно - внутренние, психологические цели самонаблюдения» ${ }^{17}$. Очевидно, что какими бы различными качествами не обладали речения и сколь бы гетерогенными они ни были, всё же в масштабах «безмерного и замирного» (В.Хлебников), то есть космического устроения находятся аргументы для осмысления их единства и даже изоморфности,

\footnotetext{
${ }^{16}$ См.: Бандиленко Г. Г. Лабиринт // Мифологический словарь / Гл. ред. Е. М. Мелетинский. М., 1991. С. 308.

${ }_{17}$ Алексеева В. Путешествие в настоящее // Гурджиев Г. И. Жизнь реальна только тогда, когда «Я есть». - M., 2004. С. 221.
} 
правда, постигаемой с большим трудом. По крайней мере, мы ещё не чувствуем под собой такой логической основы, благодаря которой возможно было бы доказательно иллюстрировать выдвинутый тезис. Поэтому отложим решение проблемы на будущее, держа в памяти древнюю философско-эзотерическую максиму: «То, что внизу, то и вверху».

Теперь, развивая тему, самое время сказать о такой специфике лабиринта, которая, несомненно, является главной в его характеристике, а для нашего исследования - неустранимой из корпуса искусства и литературы начала XX столетия. Как, вероятно, догадывается читатель, речь идёт о фигурности лабиринта и, в первую очередь, о таком его выразительном символе, как спиралевидность. Тут не место развёртывать соответствующий анализ этого понятия в его подробном описании. Скажем о том, что непосредственно корреспондирует с задачами авторского труда. «Спираль, - один из глубочайших символов Вселенной, - указывается в научной литературе. - И Космос сам испещрён и пронизан спиральными галактиками и вакуумными квантовыми вихрями. Спираль - единый код единого мира, заложенный Матерью-природой в фундамент всего живого и неживого. Вспомним, - говорится далее, - знаменитую двойную спираль Уотсона-Крика, представляющую собой молекулярную модель генетического кода. Без него невозможна преемственность поколений, передача наследственных признаков от родителей к детям. Но если спуститься глубже, почти на самое «дно» материи, то и там обнаруживаются аналогичные закономерности. По новейшим данным <...>, «последней» природной стихией, лежащей в основе мироздания и уже используемой на практике, выступают так называемые торсионные («скрученные») поля, допускающие мгновенное распространение любой информации. Эти поля кручения, - формулируется вывод, - связывают воедино все уровни природной иерархии и позволяют естественным образом объяснить многие доселе непостижимые чудеса ${ }^{18}$.

Всё сказанное вполне может претендовать на статус формульно-обобщённо-

\footnotetext{
18 Дёмин В. Н. Гиперборея. Исторические корни русского народа. М., 2005. С. 187-188.
}

го итога, обозначающего теоретический смысл тщательно собранного и проанализированного материала. Что же касается «лабиринта», то он выступает в роли образа, концентрирующего в себе многообразную проблематику. Недаром сказано, что это - символ. Нам хочется продолжить эту мысль и подчеркнуть в ней доминирующее содержание, именно, спиралевидность, «в которой закодирован глубочайший и древнейший вселенско-космический смысл, трансформированный в самых неожиданных формах» ${ }^{19}$. Почти невозможно найти вид искусства, который мог бы обойтись без фигуры спирали, начиная с неразгаданных древнейших рисунков в пустыне Наска и античных колонн (ионический ордер). В этом же ряду находится изображение спирали, выбитой на бивне мамонта и имеющей космическое содержание (найдена на территории Западной Сибири ${ }^{20}$. Сюда же должны быть помещены иллюстрации с космической символикой, украшавшей русскую утварь и предметы домашнего обихода: прялки и ковши, спинки скамей и кроватей, тележные борта и дуги, и др. ${ }^{21}$ Спиральный орнамент нашёл широкое распространение в русских вышивках, в комплексах заклинательной орнаментики, в символах земли и солнца на причелинах и «полотенцах» русской избы ${ }^{22}$. Таким образом, ясно, что спираль, эта формообразующая фигура лабиринта, получила в истории культуры своё, весьма значимое, место. Эта фигура внедрена в самые разные виды творчества, не только не теряя, но, напротив, расширяя своё содержание, вплоть до космической его семантики. Она вплетена в дивные узоры вышивки и зодчества, в их орнамент и стилевую декоративность. Подобная многофункциональность спирали и - шире - космического лабиринта - обнаруживается в структурном устройстве литературных форм Серебряного века. Однако здесь всё же отметим, что составность художественной речи новой парадигмы в одном из пунктов демонстрирует своё отличие от

\footnotetext{
19 Там же. С. 173.

${ }^{20}$ См.: Там же. С. $167,172$.

${ }^{21}$ См.: Там же. С. 176.

${ }^{22}$ См.: Рыбаков Б. А. Язычество Древней Руси. М., 1987. С. 475-479, а также: он же. Язычество древних славян. М., 1981.
} 
лабиринта в его древнем понимании. Различие проявляет себя в горизонте закрытости/открытости, завершённости/незавершённости, герметичности/безграничности (бездны) и т. п. Мифологический лабиринт, повторим, не имеет выхода, по крайней мере, знаемого. Чтобы выбраться из него, требуется поводырь или [та самая...] ариаднина нить. А вот стили новой формации, созданные в проекции лабиринта, принципиально открыты, в них можно беспрепятственно войти и так же свободно выйти. Но из какой точки и в какой пункт возможен вход/выход? - Из непостижимого небытия - в неисследимое ничто. Иначе говоря, погружаясь во тьму меона, а затем в световую стихию Логоса, на выходе из него мы вновь оказываемся в просторах трансфинитной ничтойности. Наше аналитическое путешествие «сквозь литературу» (выражение Б. М. Эйхенбаума) - довольно сложное интеллектуальное приключение, создающее ситуацию, запечатлённую в термине «между». Наука знает об опыте размышлений на эту тему М. М. Бахтина, М. Бубера, Г. Шпета и современных учёных, развивающих творчески питательную традицию. В области поэтики и стилистики она нуждается в специальной разработке. Здесь мы кратко скажем о существенном моменте проблемы, обратив внимание на следующее.

Как установлено, эстетическое высказывание нового типа - волнообразно, оно имеет квантовую специфику, определяющую его развёрнутость вовне, достигнутую за счёт неизбежной разрывности речения, охваченного спиралевидной фигурностью, представленной в масштабах вселенского дизайна, куда ввергнуты вербальные единицы и их комплексы. Но, спрашивается, где же располагается интенсивно значимая семантика подобных эстетических конструкций? Ответим на этот вопрос так: она находится там, где присутствует слово, которое, впрочем, не исчерпывает выражаемого содержания, выплёскивающегося в дали открывшейся безмерности. Однако в этом вакууме слово утрачивает свою морфность и, следовательно, определённость предметного значения. И всё же надежда на обнаружение объёмного содержания необычных эстетических высказываний остаётся - именно, тогда, когда оно полагается в некой срединности, в междуцарствии слова и не-слова, то есть ничтойности в одних случаях никак не обозначенной символически, знаковым образом, в других же - сло́ва и всё той же ничтойности, но маркированной точечно-линеарными ресурсами стиля. Глубинное содержание таких высказываний не сводимо ни к вербальной массе, ни к собственно бездне, её обымающей и пронизывающей. Речь идёт о чём-то третьем и далёком от логизированных идентификаций. Но что собою представляет это «третье»? Мы будем правы, если скажем, что анализируемая поэтика предполагает читателя, «открывающего для себя в пространстве между существование аффективно-смысловой сферы» ${ }^{23}$. Слово здесь непредставимо в отрыве от его инаковости, а та, сто́ит ей оказаться отлучённой от логосных энергий, сразу же лишается своих творческих импульсов. Точка схождения двух стихий - словесной и меональной - есть срединность или то «между», где располагается вероятностно-символическое содержание речения и стиля в целом.

Это утверждение, в общем, верно, что не мешает указать на некоторую его недоговорённость. В самом деле, в живой практике художественной речи мы видим, с одной стороны, максимальное сближение письменно данного слова и зон меона; с другой, за пределами их взаимодействия, то есть активного и динамического процесса порождения новых смыслов и эмоциональных обертонов, остаётся то глухое пространство страницы, которое не то что не охвачено словом, но и недосягаемо для его, слова, семантической радиации. То, что называется выразительно-смысловым контекстом нарративности, формируется в гуще логосно-меональных коловращений, а не в пространстве беспредикативного нейтрализма. Напомним, что так мы вернулись к проблеме уконических сегментов стиля. В самом наличии этих сегментов нет ничего удивительного, потому что "неисследимое» - беспредельно, а укон и есть постоянно возобновляющаяся стихия безграничья, служащая ресур-

\footnotetext{
${ }_{23}$ Зинченко В. П. Психология на качелях между душой и телом // Психология телесности между душой и телом / Ред.-сост. В. П. Зинченко, Т. С. Леви. М., 2007. С. 25.
} 
сами для возможного разрастания текста. И пусть вот сейчас, сиюминутно, он - не участник когнитивных и морфологических метаморфоз в лоне телеологических структур, но, не будь его, никакая эволюция стиля - вдаль, вширь и по вертикали была бы невозможна. Укон - основа, материал и гарант творческого потенциала поэтологических конструкций. По этой причине он входит в их составность как высказывание, хотя и с абсолютной неопределённостью в плане языковой семантики и морфности. Повторим соображения Ж. Делёза о том, что укон - не только негативность, но сфера проблем и вопросов. Однако оставим эту тему, чтобы конспективно изложить следующее.

Выше мы имели возможность убедиться в том, что структурное устройство литературных стилей необычной формации включает в себя такие морфологические компоненты, которые обогащают составность поэтики классического образца. Это не могло не привнести изменений во внешний, фигурный облик словесного искусства, а также в его интонационный строй. Глаз и слух читателя теперь должны были стать более острыми и чуткими, чтобы адекватно реагировать на особенности художественной машинерии. Однако восприятие литературно-художественного искусства резко повышает роль и такого естественного его компонента, каким является дыхание. Согласитесь, что следить за ритмом змеящихся речений (названных С. Маковским «чудом»), внезапно исчезающих, чтобы затем найти своё продолжение, возникая из небытия, - для произнесения такого, синтаксически прихотливого, текста необходима перестройка дыхания человека, воспитанного на традиции риторико-классической культуры с её ритмической мерностью и структурной упорядоченностью любого дискурса. Мы напоминаем эти характеристики новой поэтики, увидев их извне, с позиций наблюдателя. Но ведь они воссозданы творцом текста, художником, захваченным импровизационными импульсами и их творческим напором. Как только заговоришь об этом, тут же коллеги-филологи спешат напомнить, что подобная эмфатика им известна из истории литературы, например, в романтизме она встречается весьма часто. Здесь происходит столкновение с хаотичностью формы и отсутствием каких-либо обязательств автора перед рациональной поэтикой. Так что, - продолжается комментарий, - новые стили на самом деле не новые, а эпигонские, доводящие поэтику романтизма до кричащей гипертрофии. Мы сознательно уклонимся от возможной полемики и обратим внимание на то обстоятельство, что искусство изучаемой нами эпохи имеет дело не только с ближним, но и с далевым контекстом. Скажем больше: ...и с такими концептами, которые восходят к докультурным горизонтам сознания. Поэтому исследователь свободен в выборе как векторов своих штудий, так и периодов, которые ему представляются в качестве наиболее подходящих для объяснения значимых явлений художественного творчества. В таких координатах нами отдаётся предпочтение а) архетипным моделям и инвариантным структурам, а также б) подобным образованиям, ментально близким национальной культуре. В первом случае имеется в виду теоретико-философские обоснования феномена дыхания, обоснования, находимые, например, в «Упанишадах», известных ещё с XIX века некоторым европейским мыслителям; во втором случае речь идёт о дыхательно-молитвенной практике православного исихазма, чья традиция в русской культуре насчитывает не менее четырёх столетий. Конечно же, молитва есть молитва, а поэзия (в широком смысле слова) имеет собственные задачи и цели, но необходимо видеть пункты пересечений между различными формами духовного творчества, восходящего к единому корню мифологического ритуала. При поэтологическом исследовании проблемы становится очевидным то, что уяснено современной философской мыслью, которая дифференцирует гуманитарную парадигму эпохи, выделяя в ней духовную, религиозную, социальную, культурную и народную традиции ${ }^{24}$. Все они составляют антропологическую доминанту времени - с заострением в ней роли отношений в модусе «Духовная тра-

24 См.: Хоружий C. С. Введение: О духовной традиции вообще и русской в частности // Хоружий C. C. Опыты из русской духовной традиции. М., 2005. C. $14-17$. 
диция - Культурная традиция ${ }^{25}$. Между содержательными аспектами новой поэтики и исихазмом как мета-антропологической практикой залегает, что естественно, полоса различий и её нужно принципиально учитывать, а не идти на поводу моментов структурного сходства в само́м процессе умного делания. К настоящему времени существует, хотя и немногочисленная , научная литература, намечающая подступы к тематизируемым вопросам. В дальнейшем при рассмотрении литературно-художественного творчества Серебряного века мы не минуем их.

Такова - в самом общем виде - поэтика, которую мы намереваемся реконструировать в последующих трудах. С опорой на сказанное в монографии «Меон и стиль» нам предстоит рассмотреть ранее выдвинутые теоретические категории - в их расширенном объёме, в конкретной манифестации в составе стиля и в разнообразии его индивидуально-личностных преломлений. Мы писали, что стиль - проекция космоса на страничное пространство и что именно здесь реализуются художественные замыслы писателей, видящих жизнь своих персонажей как космодраму, корни которой не только в социальных формах бытия. Они, эти корни, углублены в характерологических особенностях личности, тайна которой находится в её стиле как космологическом явлении (В. В. Розанов). Для литературоведов проблематизируется их профессиональный уровень в том случае, если они пройдут мимо этой специфической черты художественного творчества. Но с чего начать анализ теоретических оснований изучаемой поэтики? Подобный анализ следует открыть рассмотрением дефиниции, к сожалению, не встречающейся в современных литературоведческих исследованиях. (1) Это - укон. Мы знаем, что данное понятие беспредикативно и бескачественно, что, по Платону, однако, не мешает ему быть мыслимым в модусе высказывания, которое выше, шире и глубже всякого бытия и всякого мышления. Несмотря на свою речёвость, укон не выражается семиотическими, знако-

\footnotetext{
${ }^{25}$ См.: Хоружий С. С. К антропологической модели Третьего тысячелетия // Философия науки. Вып. 8. M., 2002.
}

выми средствами, поэтому для того, чтобы вовлечь его в сферу какой-либо идентификации, необходимо подъять эту стихию до уровня (2) меона с его порождающими импульсами. Как осуществить эту операцию? Мы не пишем философский трактат, наше исследование - филологическое и потому скажем, что для достижения поставленной цели достаточно ввести в уконическую бездну что-либо из символизирующих ресурсов Логоса, например, наименьшую из «теловидностей» (Прокл) - точку. Как только это действие произведено, ситуация кардинально изменилась: то, что было запредельным и беспредикатным, обогатилось некоторыми признаками качественности. Укон не превратился в структуру, но обрёл центрированность и интенцию к какой-то семантике. Умножение точки привело к линеарным образованиям - к геометрическим фигурам. В целом же, этот процесс есть не что иное, как освоение уконической просторности, освоение, представленное не средствами вербального, а пока лишь (3) начертательного потенциала логосной мощи. Но и в этом мы видим огромное событие - перевод укона в меон, а последнего как импульсного безграничья - в пределы стиля, точнее, в его строящееся бытие. Несколько позднее оно, это бытие, будет усилено (4) вербализованной энергией и доведено до подлинно смыслового высказывания. Описанный процесс - это процесс эволюции за-предельного (то есть того, что находится в пространстве до текста и - после него) в план эстетической выразительности. Теперь, когда гуща меона оказалась в связи с начертательной, морфной и семантической характеристиками Логоса, мы вступили в полосу их творческого взаимодействия, но не в синтаксически сжатом пространстве классического дискурса, а в неисследимой стихии трансфинитных структур с их развёрстостью, то есть открытостью вовне. С этого рубежа нам представляется возможным увидеть и понять оригинальные конфигурации «сцеплений» слова и не-слова или слова и его мнимости. С точки зрения позитивистски настроенного лингвиста, вторая часть высказывания не есть собственно текст, но всего лишь его «симуляция». И, тем не менее, эстетическая информация источается не только из 
словесной составности стиля, но и из того его сегмента, который в эпоху Серебряного века ассоциировался с «нулём формы». Заметим, что в наше время фиксируемая проблема осознаётся скорее искусствоведами, нежели филологами, но важен сам факт её научной актуализации.

Итак, поэтика неразрешимостей культивирует синтез текста как вербального образования и не-текста. При этом сколько-нибудь внятных аргументов в пользу связи и чередования того и другого не предлагается. Но поразительно то, что в результате мы имеем эффект целостно организованного эстетического сообщения. Новизна тут в том, что речевые компоненты не соединены друг с другом, а разъединены. Но что же соединено? - В противоположность классике - не слово со словом, подобное с подобным, а - элементы разнородного плана, причём, не по какой-то, раз принятой, схеме, но в самом разнообразном и неожиданном её применении. Соединяется традиционно понимаемый текст и то, что, в аристотелевском смысле, назвать таковым нельзя. И где логика в такого рода «единствах», разглядеть невозможно. Но писатель умудряется сблизить противоположности, создавая, тем самым, (5) акаузально гармонизированные комплексы неразрешимостей. Художественная речь конструируется (6) в вероятностно-символическом ключе, чтобы стиль не утратил эстетической идентификации. А о том, что фигурный характер неведомой до начала XX века специфической целостности новой поэтики во многом определяется моделью языкового кванта, - об этом мы специально писали ранее, в том числе и в упоминавшейся книге.

Если быть кратким, то надо сказать, что в рассмотренных эпизодах наблюдаются моменты встречи Логоса (как начала и конца классической парадигмы творчества) с его (7) запредельной сферой, этой областью (8) несказа́нного и (9) невыразимого, на чём созидается (10) метатекст как структурно-бесструктурное единство.

Впервые в истории литературного творчества была создана поэтика, которая принципиально выдвигала (11) момент кривизны, асимметричности и разуплотнённости пространства, как оно дано в начертательной практике идиостилей.
Возможно, что эта сторона дела ослабляет (12) целеполагающий аспект текста. Однако тот, кто подумает, будто бы здесь искусство утрачивает всякую внутреннюю сопряжённость, отдавая себя во власть анархии и абсурда, грубо ошибается. Возражение скептикам, признаемся, даётся не без трудных, если не мучительных, поисков доказательного ответа, но он всё же есть. Не забудем, что какими бы причудливыми ни были точечно-линеарные узоры стилей с их лабиринтной запутанностью, в конечном счёте, они поддаются охвату (13) общей для них фигурностью, именно спиралью с её космической масштабностью, (14) обнимающей и знаково данную «теловидность», и бесплотное зияние безмолвия.

Эту краткую типологическую сводку мы продолжим такой чертой новой поэтики, как её (15) фоноцентрическая специфика. Написанное теперь требует и созерцания, и чтения, и произнесения. Ну, а если мы помним (16) об импровизационности художественной речи, то тут уж невозможно забыть о её (17) дыхательной практике, заявляющей о себе (18) в контексте хореографических, танцевальных ритмов лингвистики текста и его мнимости. Эта мысль достойна того, чтобы быть поданной в расчёте на её важный акцент. Ранее была отмечена в высшей степени показательная особенность новых стилей, состоящая в том, что их «начало» и «конец» углублены во тьму меона и, скажем больше, - в уконическую безосновность, куда устремляются и там теряют свою морфность и логосное содержание, и всякая «теловидность», будь это точка, линия или само слово. Это - (19) мифологический сегмент поэтики, не лишённый свойства внушать нам некое мистическое чувство вселенскости и угасающего творческого дара человечества. И мы, признаемся, остро переживаем подобные внушения, но, к счастью, не настолько, чтобы быть ими надолго захваченными. Ведь (20) исследуемая поэтика - и сложна, и мудра, но она же и ювенильна, молода - хотя бы потому, что не отказывается от черт, присущих первозданному искусству, например, танцу, этому символу детскости, чей «запутанный» рисунок отражал движение небесного свода и составлял непременный признак как древних ритуалов, 
так и праздничных игр, а уж затем приобрёл право на самостоятельность как вид искусства. Присутствие элементов танцевальности в высших типах творческой деятельности прямо указывает на мифологические истоки последней. Современный исследователь пишет, что «любое хореографическое высказывание строится на основе некоторых механизмов, неизменных во времени, причём синтаксис и семантика хореографической фразы (будь то отдельный танец или целый балет) определяется особенностями мифопоэтического восприятия действительности в данную эпоху» ${ }^{26}$.

Как видим, поэтика, которую мы пытаемся реконструировать, отличается своей разносторонностью и широтой в охвате актуализируемых ею концептов. На фоне литературно-художественной практики Ceребряного века теоретические попытки её осмысления недостаточно отражали полноту явления, что исторически обусловливалось задачей построения «теории искусства в одном измерении ${ }^{27}$. На основе опыта символизма была сформулирована семантическая концепция творчества, а в соответствии «с иной художественной практикой, главным образом, футуризма и авангардизма, лежит синтактика» ${ }^{28}$. Ю. С. Степанов констатирует, что «полностью ни один опыт не удался; но все они взаимодополнительны» ${ }^{29}$. Это, бесспорно, верный вывод. Заметим также, что мысль о взаимодополнительности доминантных принципов может быть упрочена, вопервых, тем соображением, что символизм, например, А. Белого немыслим вне связи с активным использованием «графической риторики», в том числе и в её «сдвигологических» формах. Что же касается семантики футуризма, то и здесь мы видим усилия творцов произведений, направленные на расширение значения слова и вообще вербального уровня эстетических высказываний. Проблемы футуристической «зауми» и символистской «невнятицы» - феномены одного порядка, знаменующего

\footnotetext{
${ }^{26}$ Маликов E. B. Миф и танец. Опыт занимательной герменевтики. М., 2012. С. 9.

${ }_{27}$ Степанов Ю. С. В трёхмерном пространстве языка (Семиотические проблемы лингвистики, философии, искусства). М., 1985. С. 67.

${ }_{28}^{28}$ Там же.

${ }^{29}$ Там же.
}

парадигмальное единство двух стилей, хотя и несоизмеримых по своей роли в истории литературы. Но тут следует обратить внимание на одно обстоятельство, о котором, кажется, знают многие, однако пишут мало. Речь идёт о том, что в начале $\mathrm{XX}$ столетия эстетические манифесты составлялись не столько критиками, сколько самими писателями ${ }^{30}$, которые и стремились реализовать их в своём творчестве. Однако вот вопрос: насколько «изоморфны» декларации и их эйдологический результат? Конечно, доминантные задания и установки находили претворение в художественных произведениях, но были ли последние всего лишь иллюстрациями когнитивного дискурса? Ответ очевиден, но мы всё-таки скажем, что разминовение творческой практики с положениями деклараций нередко было столь широким и содержательно ценным, что имеются все основания, чтобы воздать хвалу творцам поистине великой литературы. Несмотря на то, что тексты манифестов весьма часто демонстрируют смешение с художественной наррацией, они, по определению, не могут прогнозировать её эстетическое своеобразие, укоренённое не только в стиле писательской индивидуальности, но и в архетипной системе мифологии, а часто и в её потаённых слоях ${ }^{31}$.Новую поэтику невозможно отнести к какой-либо одномерности. Для примера скажем так: мы вознамерились разобраться в семантике слова, для чего, первым делом, описали его лексическое значение и то «поэтическое приращение» (В. В. Виноградов), которое оно приобрело за счёт контекста стиля. Имеем ли мы право полагать, что справились с задачей? - Нет, у нас отсутствует аргумент в пользу положительного ответа на этот вопрос. Почему? Потому что содержание слова не совсем похоже на его классическую когнитивность, ведь оно обращено не только к соседнему слову и речевому мно-

\footnotetext{
${ }^{30}$ См.: Шукуров Д. Л. Концепция слова в дискурсе русского литературного авангарда. СПб.; Иваново, 2007.

${ }^{31}$ Рассмотрение затрагиваемой темы см., напр.: Лахман Р. Демонтаж риторики. Риторическая традиция и понятие поэтического. СПб., 2001; Мороз О. Н. Литературный манифест в России конца XIX - начала XX века // Альянс: Актуальные проблемы журналистиковедения и смежных областей знания: Сб. ст. / Отв. ред.-В. И. Чередниченко. Краснодар, 2009. С. 155-179.
} 
жеству вообще, но и к трансфинитности, которая разверзается вокруг слова и его комплексов. Для филолога это означает, что исследовав специфику описанной ситуации, он обязан обратить внимание на эффект излома и извива речения, внезапного исчезновения какой-то его части и столь же неожиданного возвращения её в коммуникационную систему, хотя уже и в трансформированном виде. Но отсюда начинается слежение за процессуальностью стиля, что опять-таки открывает новые горизонты его научного постижения. (21) Так что специалист найдёт понимание с нашей стороны, если примется за исследо- вание новой поэтики с позиций не одной, а буквально несчётных её доминант. Само собой разумеется, что его анализ может быть сдобрен современными технологиями, заимствованными из области эстетики, философии, физико-математических методик и, в конце концов, из такой отрасли знаний, как антропология. Столь широкий охват предмета - скорее «проект», нежели реалистическая программа. И всё же она выполнима, хотя даже первичное её освоение требует нашего энтузиастического порыва. Сказано же Гераклитом: «Не чая нечаянного, не выследишь неисследимого и недоступного ${ }^{32}$.

\section{Список литературы:}

1. Бергер Л. Г. Пространственный образ мира (парадигмы познания) в структуре художественного стиля // Вопр. филос. 1994. № 4. С. $114-128$.

2. Булгаков С., прот. Философия имени. Париж: YMKA - PRESS, б/г [1953].

3. Гаспаров Б. М. Язык, память, образ. Лингвистика языкового существования. М.: Новое литературное обозрение, 1996. - 352 с.

4. Гиренок Ф. Абсурд и речь. Антропология воображаемого. М.: Академиче-ский Проект, 2012. - $237 \mathrm{c}$.

5. Жеребин А. И. От Виланда до Кафки. Очерки по истории немецкой литера-туры. СПб.: Изд-во им. Н. И. Новикова; Изд-ий дом «Галина скрипсит», 2012. - 480 с.

6. Кассирер Э. Философия символических форм. Т. III: Философия познания / Пер. с нем. А. М. Руткевича. М.: Академический Проект, 2011. - 398 с.

7. Керимов Т. Х. Бытие и различие: генеалогия и гетерология. М.: Академиче-ский Проект, 2011. $-256 \mathrm{c}$.

8. Лосев А. Ф. Философия имени. М.: Академический Проект, 2009. - 300 с.

9. Налимов В. В. Спонтанность сознания. Вероятностная теория смыслов и смысловая архитектоника личности. Изд. 3-е. М.: Академический Проект; Парадигма, 2011. - 300 с.

10. Фатеева Н. Синтез целого: На пути к новой поэтике. М.: Новое литературное обозрение, 2010. - $352 \mathrm{c}$.

11. Франк С. Л. Сочинения. М.: Изд-во «Правда», 1990. - 608 с.

12. Хайдеггер М. Исток художественного творения / Пер. с нем. Михайлова А. В. М.: Академический Проект, 2008. - 528 с.

13. Хоружий С. С. Опыты из русской духовной традиции. М.: Изд-ий дом «Па-рад», 2005. - 448 с.

14. Ямпольский М. «Сквозь тусклое стекло»: 20 глав о неопределенности. М.: Новое литературное обозрение, 2010. -688 с.

\section{References (transliteration):}

1. Berger L. G. Prostranstvennyi obraz mira (paradigmy poznaniya) v struktu-re khudozhestvennogo stilya // Vopr. filos. 1994. № 4. S. $114-128$.

2. Bulgakov S., prot. Filosofiya imeni. Parizh: YMKA - PRESS, b/g [1953].

3. Gasparov B. M. Yazyk, pamyat', obraz. Lingvistika yazykovogo sushchestvovaniya. M.: Novoe literaturnoe obozrenie, 1996. - $352 \mathrm{~s}$.

4. Girenok F. Absurd i rech'. Antropologiya voobrazhaemogo. M.: Akademiche-skii Proekt, 2012. $237 \mathrm{~s}$. 
5. Zherebin A. I. Ot Vilanda do Kafki. Ocherki po istorii nemetskoi litera-tury. SPb.: Izd-vo im. N. I. Novikova; Izd-ii dom «Galina skripsit», 2012. - 480 s.

6. Kassirer E. Filosofiya simvolicheskikh form. T. III: Filosofiya poznaniya / Per. s nem. A. M. Rutkevicha. M.: Akademicheskii Proekt, 2011. - 398 s.

7. Kerimov T. Kh. Bytie i razlichie: genealogiya i geterologiya. M.: Akademiche-skii Proekt, 2011. $256 \mathrm{~s}$.

8. $\quad$ Losev A. F. Filosofiya imeni. M.: Akademicheskii Proekt, 2009. - 300 s.

9. Nalimov V. V. Spontannost' soznaniya. Veroyatnostnaya teoriya smyslov i smyslovaya arkhitekto nika lichnosti. Izd. 3-e. M.: Akademicheskii Proekt; Paradigma, 2011. - 300 s.

10. Fateeva N. Sintez tselogo: Na puti k novoi poetike. M.: Novoe literaturnoe obozrenie, 2010. - $352 \mathrm{~s}$.

11. Frank S. L. Sochineniya. M.: Izd-vo «Pravda», 1990. - $608 \mathrm{~s}$.

12. Khaidegger M. Istok khudozhestvennogo tvoreniya / Per. s nem. Mikhailova A. V. M.: Akademicheskii Proekt, 2008. - 528 s.

13. Khoruzhii S. S. Opyty iz russkoi dukhovnoi traditsii. M.: Izd-ii dom «Pa-rad», 2005. - $448 \mathrm{~s}$.

14. Yampol'skii M. «Skvoz' tuskloe steklo»: 20 glav o neopredelennosti. M.: Novoe literaturnoe obozrenie, 2010. $-688 \mathrm{~s}$. 